\title{
Issue Costs and Common Stock Offerings
}

\author{
Robert M. Hull and Robert Kerchner
}

Robert M. Hull is an Associate Professor of Finance and Robert Kerchner is an Associate Professor of Econometrics. Both are at the Washburn University School of Business.

\begin{abstract}
Prior research of common stock offerings reaches different conclusions concerning the impact of issue costs on stock value. We identify factors that can best explain the different findings - most prominent are the issue costs measure and the listing. We investigate 323 common stock offerings and find that $\$ 61$ of every $\$ 100$ fall in stock value can be attributed to issue costs. The respective dollar amounts for the samples of OTC, AMEX, and NYSE firms are $\$ 72, \$ 69$, and \$38. These findings suggest that the collective impact of the negative wealth effects from managerial signaling may be less important than generally assumed.
\end{abstract}

Mikkelson and Partch (1986) and Hull and Fortin $(1993 / 1994)$ are the only studies to examine in detail the impact of issue costs on announcement period stock returns for equity offerings. These two studies reach different conclusions. Mikkelson and Partch (1986) find that offering costs are a relatively small portion of the negative announcement period return, while Hull and Fortin (1993/1994) show otherwise. This disagreement motivates our research as we aim to explain the different conclusions concerning the wealth impact of issue costs. In the process we hope to understand the situations for which issue costs can significantly impact common stock value.

We begin our research by examining the literature in order to discover factors that can help explain the different conclusions. We identify four potentially relevant factors: the measure of issue costs; the listing of the firms in the sample; the percentage change in outstanding common stock caused by the new offering; and the inclusion or exclusion of combination offerings.

We select a sample of 323 common stock offerings and investigate this sample in light of the above four factors. First, we use (for the most part) an issue costs measure that is a compromise between those used by the two prior studies. This measure includes cash flotation costs (consisting of the underwriting spread and fees associated with administration, registration, and legal services) and underpricing. The use of the term "cash" captures the fact that these costs cause an immediate cash compensation for investment bankers. Second, in our analysis, we include an examination of samples of OTC $(n=106)$, AMEX $(n=107)$, and NYSE $(n=110)$ firms. Third, we screen out issues that involve very small changes in common shares (and for which an issue costs effect is not of economic significance). Finally, we investigate both primary and combination offerings. ${ }^{1}$

We summarize our results when cash flotation costs and underpricing are used to measure issue costs. When testing our total sample, we find that the average fall in common share value that can be attributed to issue costs is $-1.59 \%$, as compared to the average twoday fall in stock value of $-2.62 \%$. The mean fall in stock value represents $61 \%$ of the mean fall in stock value.

\footnotetext{
${ }^{1}$ Like others (e.g., Hull and Fortin, 1993/1994; and Hull and Moellenberndt, 1994), we classify an observation as a combination offering when the primary component of the common stock offering is accompanied by a registered secondary component that is at least $10 \%$ of the combined primary and secondary components.
} 
Thus, if we compare averages, about $\$ 61$ of every $\$ 100$ fall in stock value can be accounted for by issue costs. The dollar amounts for the OTC, AMEX, and NYSE samples are $\$ 72, \$ 69$, and $\$ 38$ for every $\$ 100$ fall in value, respectively. We also show that the dollar amounts (per \$100 fall) are greater when we analyze samples where the percentage change in common stock is greater or where combination offerings are excluded.

Finally, we perform tests after adjusting announcement period returns for the negative effect caused by issue costs. Although these adjusted returns remain negative even after removing the negative issue expenses effect, we find that these returns are no longer significantly different from zero for either the OTC or AMEX sample. These insignificant results appear to suggest that negative wealth effects typically cited by the literature (e.g., signaling, agency, and tax effects) may not be present for OTC and AMEX firms. However, these results do not necessarily rule out a variety of negative effects for individual announcements, but only serve to highlight the possibility that these negative effects might be, on average, neutralized by positive wealth effects. The challenge for future research is to identify and examine both the negative and positive wealth effects that can accompany a stock offering announcement.

\section{Issue Costs Research}

In this section, we review the literature and identify factors that can explain the different conclusions concerning the impact of issue costs on common stock value. These factors guide our sample selection and empirical tests.

\section{A. AMEX/NYSE Research}

The research by Mikkelson and Partch (1986) was the first study to compare the issuance fees for security offerings with the announcement period stock returns. They analyzed 299 public security offerings occurring from 1972 through 1982. Their investigation includes 80 AMEX/NYSE cash offerings of common stock where the proceeds are used primarily to change the asset structure. These 80 stock offerings include 23 combination offerings.

For their stock offering sample $(n=62)$ that excludes canceled and right offerings, Mikkelson and Partch (1986) find a mean two-day cumulative abnormal return (CAR) of $-3.46 \%$. For the firms in this sample for which issue cost data appear to be available $(n=46)$, they find that the negative cash flow stemming from cash flotation costs averages $-0.7 \%$ of the preannouncement period common stock value. Since they do not report the announcement period fall in stock value for observations for which issue costs data are known, we cannot precisely compare the mean $-0.7 \%$ cash outflow from issue costs to the mean percent fall in stock value for these observations. ${ }^{2}$ Nevertheless, they infer that issue costs are not large enough to explain the negative market reaction to the stock offering announcements.

The conclusion of Mikkelson and Partch (1986) concerning the role of issue costs suggests several crucial assumptions. First, issue costs (like other hypothesized effects associated with unexpected stock offerings) impact stock price at the time of the announcement. This first assumption is affirmed by Asquith and Mullins (1986), who note that current common shareholders bear the costs of issuing. It is also consistent with the finding that primary equity offerings are infrequent events (e.g., McDaniel, Madura, and Akhigbe, 1994; and Light and White, 1979). Such infrequency suggests uncertainty about the timing, that is, will the offering occur this year, in 20 years, or ever? Such uncertainty argues against assuming that issue costs are already largely impounded in stock prices. ${ }^{3}$

Second, a $-0.7 \%$ fall in stock value caused by issue costs is not enough to explain an announcement period fall in stock value of around $-3.5 \%$. Thus, this second assumption suggests that a mean fall due to issue costs, as a percentage of a mean two-day CAR, that is below $20 \%$ is not sufficient enough to cause issue costs to be a significant factor when accounting for the fall.

\section{B. OTC Research}

In an extension of Mikkelson and Partch (1986), Hull and Fortin (1993/1994) examine 150 OTC common stock offerings occurring between 1973 and 1987. Included in their analysis are 100 primary stock offerings and 50 combination offerings.

For their 100 primary offerings, Hull and Fortin (1993/ 1994) report that the negative cash flow stemming from cash flotation costs averages $-1.69 \%$ of the preannouncement period common stock value. This mean is more than $75 \%$ of their mean two-day CAR of $-2.23 \%$. When other costs are considered (namely, underpricing

${ }^{2}$ Mikkelson and Partch (1986) do not report how many of the 23 combination offerings in their stock offering sample $(n=80)$ are among the 46 observations for which issue costs data are available. Nor do they report the number of AMEX stocks and NYSE stocks among these 46 observations.

${ }^{3}$ Furthermore, if issue costs are expected and already impounded in pre-announcement period stock value, then one could argue that all effects (e.g., signaling, agency, and tax effects) associated with equity offerings should also be expected and thus already impounded. 
and warrants) in addition to cash costs, Hull and Fortin (1993/1994) estimate that the average negative cash flow due to issue costs doubles, causing these combined costs to be greater than the average fall in stock value. Adjusting each two-day CAR (by adding the absolute magnitude of these combined issue costs per share to the announcement day closing price), they find an adjusted mean CAR that is positive $(1.15 \%)$ and significantly different from zero at the 0.05 level $(\mathrm{t}=2.14)$.

For their 50 combination offerings, Hull and Fortin (1993/1994) report findings different from their primary offerings. They find that cash costs can cause a fall in stock value that averages $-1.18 \%$, while the mean twoday CAR is $-3.92 \%$. These findings suggest that cash costs can only account for about $30 \%$ of the fall in stock value for combination offerings. When underpricing, warrants, and other costs are considered along with cash costs, they estimate that issue costs can account for up to $60 \%$ of the CAR. After adjusting CARs for all of these expenses, they find an adjusted mean CAR that is negative and insignificant at the 0.05 level. This negative adjusted CAR for their combination offering sample contrasts with the significant positive adjusted CAR found for their primary sample.

The issue expenses model of Hull and Fortin (1993/ 1994) shows that the relative size of the offering (as measured by the percentage change in share of common stock outstanding) is related to the fall in stock value. This relative size variable, along with the expected issue costs per share, are the two variables that together determine the impact of issue costs on stock value. For their total sample, they report an average percentage change in outstanding shares of $23.3 \%$. This percentage is more than one-and-one-half times greater than the $15.1 \%$ reported by Mikkelson and Partch (1986) for their sample of completed stock offerings $(n=62)$. Hull and Fortin $(1993 / 1994)$ also note that the one-third of their total sample observations $(n=50)$ with the greatest percentage changes in outstanding common stock have CARs that are significantly positive if adjusted for all issue costs.

\section{Inferences from Prior Research}

A number of factors may account for the different conclusions reached by prior researchers. First, the measure of issue costs is an important factor. Studies are more likely to find issue costs to be a significant factor if they include more than cash flotation costs. Second, the market where the shares are traded can make a difference. Hull and Fortin (1993/1994) examine an OTC sample and show that cash costs, as a percentage of common stock price, cause a negative cash flow averaging $-1.69 \%$. This average is much greater than the $-0.7 \%$ average reported by Mikkelson and Partch (1986) for their AMEX/NYSE sample. Third, the relative size of the offering seems to be a relevant factor. Thus, issue costs may not be a significant factor influencing shareholder value unless the proceeds being raised are large relative to outstanding common stock value.

Finally, the effect of combination offerings may differ from that of purely primary offerings. Hull and Fortin (1993/1994) separately analyze primary and combination offerings. Their analysis of primary offerings eliminates any "hidden" purpose (that is, insider sales) that may occur when a secondary offering is attached. As suggested by prior research (e.g., Masulis and Korwar, 1985; Hull and Moellenberndt, 1994; and Hull and Pinches, 1994/1995) combination offerings involve decreases in fractional share holdings of insiders. As posited by the signaling model of Leland and Pyle (1977), this would cause combination offerings to have more negative CARs than primary offerings (and thus have CARs which are less likely to be explained by issue costs). More negative CARs for combination offers are also consistent with agency theory since insiders include manager-agents who are motivated to behave less efficiently when their ownership proportions are lowered. In conclusion, the elimination of negative effects, associated with the selling of stock by insiders through a registered secondary offering, can explain why a primary sample of stock offerings will have a smaller negative CAR. ${ }^{4}$

\section{Data, Methodology, and Primary Tests}

In the previous section, we considered four factors capable of explaining the relative importance of issue costs: the measure of issue costs, listing, the relative size of the offering, and whether the offering is a combination offering. The sample selection criteria, issue costs measure, and tests described in this section are motivated by these factors.

\section{A. Sample}

The primary sources for the common stock offering announcement dates used here are the Investment

${ }^{4}$ The differences reported by Mikkelson and Partch (1986) and Hull and Fortin (1993/1994), which are attributed to the relative size of the offering or the inclusion of combination offerings, may be simply viewed as explaining any listing difference. For example, offerings by smaller OTC firms are characterized by greater changes in the number of outstanding shares and (as will be briefly documented later) greater insider sales when a secondary offering is attached to a primary offering. 
Dealers' Digest (IDD) and The Wall Street Journal $(W S J) .{ }^{5}$ We obtain data for summary statistics and empirical tests from $I D D, W S J$, investment bankers, COMPUSTAT Annual Files, Moody's Industrial Manual, and CRSP Price and Return Files. Our sources cover the years between 1970 and 1989 and enable us to gather information on 323 common stock offering announcements by OTC, AMEX, and NYSE-listed firms. Like Hull and Fortin (1993/1994), each offering in our sample serves to reduce debt. ${ }^{6}$ In addition, we require each offering to satisfy the following five selection criteria:

1) The firm planning the offering must have its stock listed in the CRSP Return Files and have sufficient trading data to calculate its two-day CAR (the CAR calculation is described later).

2) The firm must not be identified as a utility (since the announcement by a utility is most likely known in advance).

3) The stock offering must be a completed underwritten offering with sufficient information to determine issue costs.

4) The stock offering announcement must be free from other important firm-specific events for the two days prior to and after its announcement date.

5) The expected proceeds from the offering must

${ }^{5}$ The date of publication in WSJ of the planned offering usually occurs one business day after the announcement date given by $I D D$. Therefore, for those 42 observations for which WSJ is the only source for the announcement date (e.g., a preregistration planning date or the registration date), the business day before the date of publication in WSJ is taken as the announcement date. It can be noted that only 79 observations in our sample have a pre-registration planning date. The fact that only 79 observations involve a pre-registration announcement leads one to ponder whether or not our sources always publish pre-registration announcements. (This possibility appears to be true for the WSJ for the years after 1983 since for these years we do not find any pre-registration announcements.) Nonetheless, the CAR of $-2.73 \%$ for these 79 observations is very similar to the CAR of $-2.58 \%$ for the remaining 244 observations. Finally, for the most part, the 79 pre-registration announcements have the same information (namely, the dollar amount of the planned offering and the purpose of the offering) as the 244 registration announcements. ${ }^{6}$ We find no evidence to suggest the purpose of the offering explains why the conclusions of Hull and Fortin (1993/1994) differ from Mikkelson and Partch (1986) who investigate stock offerings where the cash proceeds are frequently used (at least in part) to increase the productive assets. Theoretically, while a debt reduction purpose ameliorates negative effects predicted by signaling models (e.g., Myers and Majluf, 1984; and Miller and Rock, 1985) tied to changes in the asset structure, it allows for negative effects predicted by the debt dependent models (e.g., Modigliani and Miller, 1963; Ross, 1977; and Fama, 1985). Empirically, Masulis and Korwar (1986) analyze primary stock offering announcements covering the years from 1963 to 1980 and find that offerings reducing debt $(n=55)$ have returns very similar to those used for capital expenditures $(n=63)$. be at least $5 \%$ of the pre-announcement aggregate market value of the company's common stock.

The last screen enables us to test a sample for which the magnitude of issue costs is more likely to cause a significant negative impact. Since stock offerings by larger NYSE firms tend to involve smaller relative changes in outstanding shares, this screen tends to delete NYSE firms as opposed to OTC and AMEX firms. $^{\text {? }}$

\section{B. Issue Costs}

In this study, we classify issue costs as "cash" and "noncash" costs. The former costs not only measure the cash received by investment bankers but also are the costs that are more accurately documented and routinely published after the announcement day. These cash costs comprise the underwriting spread (or selling concession) and "out-of-pocket" expenses incurred by the issuer. These latter expenses include the fees associated with administration, registration, and legal services.

Unlike the cash costs, the noncash flotation costs do not result in immediate cash flows for investment bankers and are more difficult to measure (and thus report). ${ }^{8}$ The largest of these noncash costs are underpricing and stock warrants. Underpricing occurs before the actual offering when the price of the new shares is set below the market price and is necessary to help insure that the offering will be sold out. Warrants are often given to the underwriters at a token cost (with their true value unreported) and are more likely to occur for offerings by smaller firms. For example, $\mathrm{Ng}$ and Smith (1996) find that the use of warrants tends to be restricted to firms with characteristics associated with small firms, such as high rates of expected stock price appreciation, important growth opportunities, and high volatility of stock return.

At the time of a stock offering announcement, the market does not precisely know the amount of the issue costs that will be incurred. To estimate the expected impact of these costs on outstanding common stock value, we need a reasonable procedure to calculate these costs. In this study,

${ }^{7}$ In particular, the last screen eliminates all but 19 private stock-for-debt swaps from the sample. Private swaps (which are typically undertaken by large firms) not only have a smaller impact on stock value due to lower issue costs (e.g., see Hand, 1989; and Rogers and Owers, 1985), but also have a smaller mean two-day CAR. The CAR is usually near or below $-1.0 \%$ (e.g., see Copeland and Lee, 1991; Finnerty, 1985; and Peavy and Scott, 1985). Ceteris paribus, one would expect a smaller mean CAR if issue costs are lower.

${ }^{8}$ Hull and Fortin $(1993 / 1994)$ do not attempt to calculate underpricing as we do, but use an ad hoc estimate for underpricing based on prior research (e.g., Ibbotson, 1975; and Smith, 1977). 
we use an ex post procedure that assumes expected costs are the same as the costs published after the announcement date. The ex post costs that we calculate are cash flotation costs and underpricing. These costs represent a compromise of the costs considered by the previous research. As noted, Mikkelson and Partch (1986) examine only cash costs, whereas Hull and Fortin (1993/1994) consider cash and noncash costs (mostly underpricing and warrants). Thus, to the extent warrants represent a significant expense, our results tend to understate (with one exception) the impact of issue costs. The exception occurs for one test (reported in Section III, D) in which we include warrants and other issue costs in an effort to repeat a test similar to one performed by Hull and Fortin (1993/1994).

We gather cash flotation costs from investment bankers and the financial press (namely, IDD) via reports made public after the offering day. We get data to calculate underpricing from the financial press and the CRSP Price Files. The financial press reports the offering date and the offering price. The CRSP Price File supplies stock price data for the period around the time of the actual offering. ${ }^{9}$

\section{Procedure to Measure Underpricing}

We now describe our procedure for calculating underpricing. We begin by defining underpricing as the negative impact on stockholders when the firm sells new shares at a price below their current market value. The cost of underpricing can be expressed as:

$$
\left(\mathrm{P}_{\text {off }}-\mathrm{P}_{\text {bef }}\right) / \mathrm{P}_{\text {bef }}
$$

where $\mathrm{P}_{\text {off }}$ is the offer price and $\mathrm{P}_{\text {bef }}$ is the current market price at the time the offer price is set (for OTC firms the current market price is the average of the bid and ask prices). Since $\mathrm{P}_{\text {bef }}>\mathrm{P}_{\text {off }}$ is expected to hold for the offering to be completed, Equation (1) is simply the percentage below the current market price at which the offering price is expected to be set. Thus, Equation (1) will typically give a negative value indicating a negative impact on shareholder wealth.

The most difficult part of estimating values for underpricing is to determine the day on which $\mathrm{P}_{\text {off }}$ is set. Although $\mathrm{P}_{\text {off }}$ is often set after the close of the market on the day prior to the actual offering, it is also quite possible that it can either be set earlier or right up to the time of the offering. In using Equation (1),

${ }^{9}$ In our analysis, we focus on issue costs that can be quantified on the basis of publicly available information. In addition to generally disregarding warrants, there are some unreported expenses that we disregard. For example, the costs involved in repurchasing outstanding debt are usually not reported. Also unreported is the value of employees' time spent on the new issue. we first calculate underpricing values by assuming $\mathrm{P}_{\text {off }}$ is set before the market closes on the day prior to the actual offering. Since we do not know the precise time during this day at which the firm announces $\mathrm{P}_{\text {off }}$, we proxy for $\mathrm{P}_{\text {bef }}$ by taking the closing price the day prior to this day (which would be the closing price two days prior to the offering day). When we follow this procedure, we find that there are 76 observations for which Equation (1) gives a positive value (that is, there is no underpricing). When analyzing these 76 observations, we find that the average market price increases +1.91 for this day (e.g., the closing price from two days prior to the actual offering to one day prior is $+1.91 \%$ ). This leads us to conclude that $\mathrm{P}_{\text {off }}$ is set either during the day after the price has risen or the next day (which is the actual offering day). In either case, a better proxy for $\mathrm{P}_{\text {bef }}$ would be the closing price the day before the offering day.

For the above 76 observations, we once again use Equation (1) but now take the closing price for the day prior to the actual offering (instead of the two days prior to the offering) as a proxy for $\mathrm{P}_{\text {bef }}$. When doing this, there are now only 16 observations for which Equation (1) gives a positive value (e.g., for which underpricing does not exist). On examination of these 16 observations, we find that the market price increases, on average, $+2.96 \%$ the day of the actual offering. Thus, to proxy for $\mathrm{P}_{\text {bef }}$ for these remaining 16 observations, it becomes imperative (if underpricing is to exist) to use the closing price on the actual offering day. After this last adjustment, we find two observations where values for $\mathrm{P}_{\text {bef }}$ are not greater than $\mathrm{P}_{\text {off }}$ and, thus, where using Equation (1) does not produce underpricing.

Our procedure for estimating underpricing is justified on the following three grounds. First, if we do not follow this procedure, we generate observations for which "overpricing" often exists. Such a situation creates an excess supply jeopardizing the completion of the offering. This is not the case for our sample, which is composed of completed offerings. Moreover, for the 76 observations-for which we proxy for $\mathrm{P}_{\text {bef }}$ by using the closing price either the day prior to the actual offering or the day of the offering - the financial press (more often than not) reports that these 76 offerings were completed quickly. Underpricing would most likely have to exist for these offerings to sell quickly.

Second, by first using closing prices two days prior to the actual offering, we minimize price pressure effects that occur on the actual offering day when the new issue reaches the market. Price pressure effects can lower the closing price on the actual offering day causing $\mathrm{P}_{\text {bef }}$ to be understated (and thus the magnitude of underpricing to be underestimated). Third, we 
repeated our procedure using a different ordering of days when proxying for $\mathrm{P}_{\text {bef }}$ and found underpricing values reasonably similar to the $-2.94 \%$ average (reported in Table 1) for our total sample. ${ }^{10}$

\section{Descriptive Statistics}

In Table 1, we report summary statistics for the total sample and three listing samples: OTC, AMEX, and NYSE. Panel A gives a time profile when the sample is divided into four time periods. This panel shows that observations occur with greater frequency during the period from 1980 through 1984, and less frequently for the period from 1985 to 1989 . The fewer number of observations for the latter period is at least partially explained by the fact that data requirements (in particular, for issue costs) are less frequently given by the financial press for these years.

Panel A further reports that a smaller number of OTC observations occur from 1970 to 1974. One reason for this smaller number is that stock return data for OTC firms does not begin until December 1972. The panel also reports that AMEX firms are relatively more frequent (compared to OTC and NYSE firms) for the years between 1970 to 1974, while OTC observations are relatively more prevalent for the years between 1975 and 1979. After 1980, we see that observations are similarly distributed in terms of listing.

The first three rows of Panel B reports mean and median statistics (in millions of dollars) for three size variables. The first row reveals that "Common Value" (the pre-announcement market value of common stock) for NYSE firms is roughly three times larger than AMEX firms and about eight times larger than OTC firms. Similar differences are reported for "Firm Value" (which includes "Common Value" and preferred stock and debt liabilities). For NYSE firms, the mean for "Proceeds" (funds expected to be raised from the planned offering) is more than twice as large as for AMEX firms and over four times larger than for OTC firms. The last two rows of Panel B give mean and median statistics (in percentages) for two relative size variables. The panel reveals that "Proceeds/Common Value" averages $21.3 \%$ for OTC firms. This is somewhat larger than the $18.7 \%$ found for AMEX firms and noticeably larger than the $13.3 \%$ reported for NYSE firms. The panel also shows that OTC and AMEX firms experience relatively greater declines

\footnotetext{
${ }^{10}$ For example, beginning with the closing price the day prior to the actual offering day-then using the closing price two days prior, followed by using the closing price the day of the offering-gives an average underpricing of $-2.47 \%$. Following this procedure is more likely to produce overpricing. If overpricing does exist and this procedure better measures underpricing, then the $-2.94 \%$ underpricing given in Table 1 overstates the true value of underpricing.
}

in outstanding debt.

Throughout Panel B, we see that the statistics for AMEX firms are more similar to OTC firms than to NYSE firms. The similarity is not explained by the fact that there are no OTC observations prior to 1973. For example, deleting the 30 AMEX observations prior to this time gives AMEX results very similar to those we report in Table 1 (as well as the empirical findings that we will subsequently report).

Panel C reports statistics for six issue costs variables. ${ }^{11}$ The panel records that "Total Cost/ Proceeds" (cash flotation costs plus underpricing as a percentage of expected proceeds) averages $-8.39 \%$ for the total sample. Thus, even without including warrants, an average firm can expect to pay about $\$ 8.39$ for every $\$ 100$ of proceeds. From the panel, we can also see that OTC firms, on average, pay $\$ 2.57$ more per $\$ 100$ than AMEX firms and $\$ 4.19$ more per $\$ 100$ than NYSE firms. The next two rows distinguish between cash costs and underpricing. We observe that OTC firms experience substantially greater underpricing compared to AMEX or NYSE firms. The difference would be even greater if we use the dealer's ask price, instead of the average of the ask and bid prices, when calculating underpricing.

The last three rows in Panel C compare issue costs with common stock value. The panel shows that "Total Costs/Common Value" averages $-1.59 \%$. Thus, assuming stock prices impound issue costs at the time of the announcement, every $\$ 100$ of outstanding common stock value should fall, on average, about $\$ 1.59$ from cash costs and underpricing. We can also see that the average fall due to these costs for NYSE firms is about one-half that of AMEX firms and roughly one-third that of OTC firms. For the total sample, Panel $\mathrm{C}$ reveals (if we compare the last three rows of the first column) that about two-thirds of the fall in stock value due to total costs can be attributed to cash costs (and, thus, about one-third to underpricing). As can be seen in the last three columns, the ratios (of cash costs to total costs) for AMEX firms and for NYSE firms are slightly greater than two-thirds, while the ratio for OTC firms is a little over three-fifths.

\section{E. Methodology and Primary Tests}

We use the ordinary least squares (OLS) market model procedure, as detailed by Brown and Warner (1985), to test whether the mean two-day CAR is equal to zero. The two days include the announcement date (day 0$)$ and the day after $($ day +1$)$. The latter day is

${ }^{11}$ For combination offerings, only the primary portion of the offering is considered when calculating issue costs statistics. This is because sellers of secondary shares bear those costs in terms of the lower value they receive when selling shares that are already outstanding. 


\section{Table 1. Summary Statistics for 323 OTC/AMEX/NYSE Common Stock Offerings, 1970-1989}

For each cell in Panel A, the percentage of the column total is given in parentheses. For each cell in Panel B, means and medians are given in millions of dollars for the first three rows and in percentages for the last two rows. For each cell in Panel C, means and medians are reported in percentages. Common Value is the shares outstanding at the time of the initial announcement times the share price (as proxied by the closing stock price the day prior to the announcement). Firm Value comprises common value, liquidation value of preferred stock, book value of all long-term debt obligations (including capitalized leases), and current liabilities. Proceeds are the planned new primary common shares times the expected offering price (as proxied by closing stock price the day prior to the announcement day). Proceeds/Common Value is (given our definitions for proceeds and common value) identical to the planned percentage change in outstanding common shares. Retired Debt is the planned reduction in the book value of debt. Total Costs include the negative cash flows incurred by residual shareholders consisting of cash costs and underpricing. Cash Costs comprise the underwriting spread and additional expenses incurred by the issuer (e.g, fees associated with administration, registration, and legal services). Underpricing is the cost stemming from selling new primary shares below their current market value. The procedure for figuring underpricing is described in Section II, C.

\begin{tabular}{|c|c|c|c|c|}
\hline & $\begin{array}{c}\text { Total Sample } \\
(n=323)\end{array}$ & $\begin{array}{l}\text { OTC Listing } \\
\quad(n=106)\end{array}$ & $\begin{array}{l}\text { AMEX Listing } \\
(n=107)\end{array}$ & $\begin{array}{l}\text { NYSE Listing } \\
\quad(\mathrm{n}=110)\end{array}$ \\
\hline \multicolumn{5}{|c|}{ Panel A. Time Profile } \\
\hline 1970 Through 1974 & $\begin{array}{c}55 \\
(17 \%)\end{array}$ & $\begin{array}{l}6 \\
(6 \%)\end{array}$ & $\begin{array}{l}33 \\
(31 \%)\end{array}$ & $\begin{array}{c}16 \\
(15 \%)\end{array}$ \\
\hline 1975 Through 1979 & $\begin{array}{c}62 \\
(19 \%)\end{array}$ & $\begin{array}{c}34 \\
(32 \%)\end{array}$ & $\begin{array}{l}11 \\
(10 \%)\end{array}$ & $\begin{array}{l}17 \\
(16 \%)\end{array}$ \\
\hline 1980 Through 1984 & $\begin{array}{l}171 \\
(53 \%)\end{array}$ & $\begin{array}{c}55 \\
(52 \%)\end{array}$ & $\begin{array}{c}52 \\
(49 \%)\end{array}$ & $\begin{array}{c}64 \\
(58 \%)\end{array}$ \\
\hline 1985 Through 1989 & $\begin{array}{l}35 \\
(11 \%)\end{array}$ & $\begin{array}{c}11 \\
(10 \%)\end{array}$ & $\begin{array}{l}11 \\
(10 \%)\end{array}$ & $\begin{array}{l}13 \\
(12 \%)\end{array}$ \\
\hline \multicolumn{5}{|c|}{ Panel B. Size Variables } \\
\hline Common Value & $322 ; 103$ & $83 ; 50$ & $227 ; 94$ & $646 ; 351$ \\
\hline Firm Value & $536 ; 164$ & $177 ; 63$ & $359 ; 141$ & $1113 ; 568$ \\
\hline Proceeds & $35 ; 16$ & $14 ; 9$ & $29 ; 14$ & $61 ; 39$ \\
\hline Proceeds/Common Value & $17.7 ; 14.5$ & $21.3 ; 18.4$ & $18.7 ; 16.2$ & $13.3 ; 10.4$ \\
\hline Retired Debt/Firm Value & $-10.6 ;-8.6$ & $-13.5 ;-12.3$ & $-11.1 ;-9.7$ & $-7.3 ;-5.8$ \\
\hline \multicolumn{5}{|c|}{ Panel C. Issue Cost Variables } \\
\hline Total Costs/Proceeds & $-8.39 ;-7.62$ & $-10.67 ;-9.71$ & $-8.10 ;-7.49$ & $-6.48 ;-5.51$ \\
\hline Cash Costs/Proceeds & $-5.45 ;-5.16$ & $-6.41 ;-6.50$ & $-5.52 ;-5.01$ & $-4.45 ;-4.26$ \\
\hline Underpricing/Proceeds & $-2.94 ;-1.90$ & $-4.26 ;-3.68$ & $-2.57 ;-1.62$ & $-2.04 ;-1.13$ \\
\hline Total Costs/Common Value & $-1.59 ;-1.13$ & $-2.32 ;-1.81$ & $-1.61 ;-1.21$ & $-0.86 ;-0.60$ \\
\hline Cash Costs/Common Value & $-1.03 ;-0.77$ & $-1.42 ;-1.12$ & $-1.09 ;-0.86$ & $-0.60 ;-0.45$ \\
\hline Underpricing/Common Value & $-0.56 ;-0.29$ & $-0.90 ;-0.51$ & $-0.52 ;-0.29$ & $-0.26 ;-0.12$ \\
\hline
\end{tabular}


important since the announcement may take place after the market closes on day 0 .

As our sample includes many small firms subject to nonsynchronous trading, we adjust our alpha and beta parameters following the Scholes and Williams (1977) procedure when calculating the CARs. Alphas and betas are figured using value-weighted CRSP NASDAQ and CRSP AMEX/NYSE market indices for respective OTC and AMEX/NYSE firms. The estimation period used in calculating alphas and betas consists of days +41 to +240 after the announcement date. ${ }^{12}$

The descriptive statistics given in the last panel of Table 1 suggest that issue costs are of economic importance. This is especially true for OTC and AMEX firms. It remains an empirical question whether CARs that are adjusted for issue costs (e.g., by adding the absolute magnitude of their costs back into the closing stock prices for day 0) will remain negative and statistically significant from zero. We use the methodology described by Hull and Fortin (1993/1994) when calculating adjusted CARs and testing whether these CARs are equal to zero. This procedure involves calculating the expected residual cash outflow from the issue costs being considered (e.g., cash costs or cash costs plus underpricing) per outstanding share and adding the absolute magnitude of this outflow to the closing stock price on the announcement day. This adjustment serves to make the closing price higher than reported. We then proceed in the usual fashion when figuring the daily abnormal return for the announcement day. Adding this adjusted daily abnormal return to other daily abnormal returns gives an adjusted CAR. The conventional two-tailed $t$ statistic can then be calculated to determine if the adjusted CAR is statistically significant from zero.

\section{Empirical Results}

In this section, we report our empirical results including our statistical findings when testing if traditional and adjusted two-day CARs are equal to zero. For OTC and AMEX samples, CARs are not statistically significant at the conventional 0.05 level when we adjust stock prices for cash costs and underpricing. By comparing the mean fall in stock value stemming from issue costs with the mean traditional two-day CAR, we show that issue costs can explain large portions of the fall in stock value. We end this section by commenting on the role of

${ }^{12}$ We choose a post-announcement estimation period since
stock issues often occur during (or toward the end) of bull
markets. This is also true of our sample. Nonetheless, our
reported results are similar if a 200 -day comparison period
before the announcement dates is used. Our results are also hypothesized wealth effects that are traditionally accepted as explaining the market reaction to equity announcements.

\section{A. Traditional Two-Day CAR Results}

In the first column of results in Table 2, we present our statistical findings for the traditional two-day CARs. From the first column results in Panels A through $D$, we see that all parametric statistics for the total sample and three listing samples are negative and significant at the one percent level when testing if a sample's mean traditional CAR is equal to zero. The nonparametric statistics are also negative and significant at the one percent level when testing if the percent positive equals $50 \%$.

Panel A reports (in the first row) a traditional twoday CAR of $-2.62 \%$ for the total sample. This two-day CAR appears to capture the effects of the announcement as CARs for longer announcement periods are similar to $-2.62 \%$. To illustrate, the 11-day CAR consisting of event days -5 through +5 is $-2.80 \%$. Our two-day CAR magnitude is consistent with recent equity offering research. For example, it is (oddly enough) identical to the $-2.62 \%$ reported by Choe, Masulis, and Nanda (1993) for the same two days. They examine 669 NYSE/AMEX underwritten common stock offerings by industrial firms covering 1963-1983. The major use of the cash proceeds for these offerings are presumably for asset change purposes (whereas firms in our sample use the proceeds to reduce debt). Our two-day CAR magnitude is greater than the $-2.34 \%$ CAR reported by Hull and Moellenberndt (1994) for the same two days. Like this study, they examine NYSE/ AMEX/OTC stock-for-debt transactions $(n=496)$. Our more negative CARs may reflect our exclusion of events with smaller capital structure changes-as greater negative signaling, agency, and tax effects are hypothesized for samples with greater changes in equity and debt. The more negative CARs for observations with greater changes in equity are also predicted by the issue costs model of Hull and Fortin (1993/1994).

Moving down the first column, we see from the first rows for Panels B through D that the $-3.24 \%$ CAR for the OTC sample is noticeably more negative than the $-2.33 \%$ and $-2.30 \%$ CARs found for the AMEX and NYSE samples, respectively. Given the less negative CAR for the NYSE sample, it is a bit unexpected-as seen in the second rows in Panels B through D-that

robust for other methodological variations including use of the equal-weighted CRSP NASDAQ and CRSP AMEX/NYSE market indices and OLS parameters that are not adjusted by the Scholes and Williams (1977) procedure. 


\section{Table 2. Two-Day Cumulative Abnormal Returns Results for 323 OTC/AMEX/NYSE Stock Offerings}

The first row for each panel reports the mean two-day CAR followed by the traditional two-tailed t statistic (when testing if the mean two-day CAR is equal to zero). The second row gives the percent of the sample CARs that are positive followed by the two-tailed binomial $\mathrm{z}$ statistic (when testing if the percent positive is equal to $50 \%$ ). The third row reports (if applicable) in parenthesis the mean fall in stock value attributed to issue costs (cash costs for the second column and cash costs plus underpricing for the third column) as a percentage of the mean traditional two-day CAR. We follow the methodology described by Hull and Fortin (1993/1994) when adjusting the traditional two-day CAR. This procedure involves calculating the expected residual cash flow of the issue costs being considered (e.g., cash costs or cash costs plus underpricing) per outstanding share and adding the absolute magnitude of this value to the closing stock price on the announcement day. This adjustment serves to make the closing price higher than reported. We then proceed in the usual fashion when figuring the daily abnormal return for the announcement day (e.g., day 0). Adding this adjusted abnormal return to the daily abnormal return for day +1 gives the adjusted two-day CAR. The conventional two-tailed test can then be conducted to determine if the adjusted CAR is statistically significantly different from zero.

\begin{tabular}{|c|c|c|}
\hline Traditional Two-Day CAR & Two-Day CAR for Cash Costs & $\begin{array}{c}\text { Two-Day CAR Adjusted for Cash } \\
\text { Costs and Underpricing }\end{array}$ \\
\hline \multicolumn{3}{|c|}{ Panel A. Total Sample $(n=323)$} \\
\hline$-2.62 \% ;-10.48 * * *$ & $-1.59 \% ;-6.37 * * *$ & $-1.03 \% ;-4.03 * * *$ \\
\hline $26 \% ;-8.40 * * *$ & $\begin{array}{l}35 \% ;-5.40 * * * \\
(39 \%)\end{array}$ & $\begin{array}{l}40 \% ;-3.73 * * * \\
(61 \%)\end{array}$ \\
\hline \multicolumn{3}{|c|}{ Panel B. OTC Sample $(n=106)$} \\
\hline$-3.24 \% ;-6.53 * * *$ & $-1.82 \% ;-3.78 * * *$ & $-0.92 \% ;-1.89$ \\
\hline $27 \% ;-4.66^{* * *}$ & $\begin{array}{l}38 \% ;-2.53 * * * \\
(44 \%)\end{array}$ & $\begin{array}{l}43 \% ;-1.36 \\
(72 \%)\end{array}$ \\
\hline \multicolumn{3}{|c|}{ Panel C. AMEX Sample $(n=107)$} \\
\hline$-2.33 \% ;-5.12 * * *$ & $-1.24 \% ;-2.61 * * *$ & $-0.72 \% ;-1.45$ \\
\hline $30 \% ;-4.16^{* * *}$ & $\begin{array}{l}39 \% ;-2.22 * * \\
(47 \%)\end{array}$ & $\begin{array}{l}44 \% ;-1.26 \\
(69 \%)\end{array}$ \\
\hline \multicolumn{3}{|c|}{ Panel D. NYSE Sample $(n=110)$} \\
\hline$-2.30 \% ;-6.91 * * *$ & $-1.69 \% ;-5.18 * * *$ & $-1.43 \% ;-4.36^{* * *}$ \\
\hline $23 \% ;-5.72 * * *$ & $\begin{array}{l}28 \% ;-4.58 * * * \\
(27 \%)\end{array}$ & $\begin{array}{l}32 \% ;-3.81 * * * \\
(38 \%)\end{array}$ \\
\hline $\begin{array}{l}* * \text { * Significant at the } 0.01 \text { level. } \\
* * \text { Significant at the } 0.05 \text { level. }\end{array}$ & & \\
\hline
\end{tabular}

this sample has the fewest percentage of observations with positive CARs (23\% compared to $27 \%$ and $30 \%$ for the OTC and AMEX samples, respectively).

\section{B. Two-Day CAR Results When Adjusted for Cash Flotation Costs}

In the second column of Table 2, we present statistical results when the traditional two-day CAR is adjusted for cash costs. The negative $t$ and $z$ statistics in this column are noticeably smaller in magnitude than the corresponding statistics in the first column. Nonetheless, each statistic in the second column is significant at the 0.01 level with one exception (which is the nonparametric $\mathrm{z}$ statistic for the AMEX test).

For the total sample, Panel A reports that the adjusted CAR is $-1.59 \%$ and the percentage of positive CARs is $35 \%$. This $35 \%$ contrasts with the $26 \%$ reported for the traditional two-day CAR in the first column. The second column of Panels B, C, and D reveals that the OTC sample again has the most negative CAR. Its adjusted CAR of $-1.82 \%$ in Panel B is slightly more negative than the $-1.69 \%$ reported in Panel D for the NYSE sample (which no longer has the least negative CAR). Panel C reveals that the AMEX sample now has the least negative CAR. Its adjusted CAR of $-1.24 \%$ reflects the large cash costs reported in Table 1 for AMEX observations.

The third row of each panel in the second column reports, in parentheses, the percentage that is derived from dividing the mean for the "Cash Cost/Common Value" (reported in Table 1) by the mean traditional two-day CAR. This percentage serves to suggest how much of a sample's two-day CAR can be accounted for by its cash flotation costs. Panel A reveals that the percentage is about $39 \%$ for the total sample. If the announcements are unanticipated and residual owners bear the costs of the new offerings, then one can expect that for every $\$ 100$ fall in stock value about $\$ 39$ result from cash costs. In our opinion, this $\$ 39$ value is too 
large to be ignored. We conclude that cash costs can exercise a substantial economic impact on outstanding stock value.

The third rows in Panels $\mathrm{B}$ and $\mathrm{C}$ reveal percentages of $44 \%$ and $47 \%$ for respective OTC and AMEX samples. These percentages are large compared to the $27 \%$ reported in the third row in Panel D for the NYSE sample. Although not reported in Table 2, combining AMEX/NYSE offerings gives $36 \%$. This percentage is noticeably greater than the estimated $20 \%$ found by Mikkelson and Partch (1986) for their AMEX/NYSE sample. The disparity in AMEX/NYSE finding between our study and the study of Mikkelson and Partch (1986) is due more to differences between two-day CARs than to cash costs. For example, whereas we find a $-2.31 \% \mathrm{CAR}$ for our AMEX/NYSE offerings, Mikkelson and Partch (1986) report a $-3.46 \%$ CAR. On the other hand, we find that cost as a percentage of common stock value is $-0.84 \%$ for our AMEX/NYSE sample. This is only $-0.14 \%$ greater than the $-0.7 \%$ reported by Mikkelson and Partch (1986). ${ }^{13}$

\section{Two-Day CAR Results When Adjusted for Cash Costs and Underpricing}

In the final column, we present statistical results when the traditional two-day CAR is adjusted for both cash flotation costs and underpricing. Results differ from those reported in the previous two columns. Most noteworthy is that parametric and nonparametric CAR statistics are now only significant for the total sample and NYSE sample tests. For the OTC and AMEX samples, the test statistics are no longer significant at the 0.05 level.

As seen in Panel A of the final column, we find an adjusted CAR of $-1.03 \%$ for the total sample. The percentage of positive CARs for this sample increases, once again, and is now $40 \%$. As reported in Panels B through D, the adjusted CARs for OTC, AMEX, and NYSE samples are now $-0.92 \%,-0.72 \%$, and $-1.43 \%$, respectively. Comparing these percentages with those in the second column, the OTC sample no longer has the most negative CAR, while the AMEX sample still has the least negative CAR. The greatest negative CAR is now found for the NYSE sample reflecting largely its much smaller values for "Total Costs/ Common Value" (as reported in Table 1). The third row in the last column of Panel A reports that cash flotation costs and underpricing can account for $61 \%$ of the total sample's two-day CAR. Panels B through D reveal that the issue costs account for greater amounts of the fall in value for OTC and AMEX samples (72\% and $69 \%$, respectively). As is true when only cash costs

${ }^{13}$ The $-0.14 \%$ difference between our AMEX/NYSE sample and the Mikkelson and Partch (1986) sample can be explained if our sample has a higher proportion of AMEX firms. are considered, the OTC and AMEX samples, once again, have percentages that are similar. The percentage given for the NYSE sample is $38 \%$ and (as is true when only cash costs are considered) is much lower than that found for the OTC or the AMEX sample.

Although not reported in Table 2, when AMEX/NYSE observations are combined the percentage is $53 \%$. This is greater than the $36 \%$ when only cash costs are considered. It is over two-and-one-half times greater than the $20 \%$ found by Mikkelson and Partch (1986). The disparity (between our results and those of Mikkelson and Partch) no longer involves just those differences attributable to two-day CARs $(-2.31 \%$ versus $-3.46 \%)$ but also involve differences in issue costs. For example, we find that cash costs plus underpricing as a percentage of common stock value is $-1.23 \%$ for our AMEX/NYSE sample. This is $-0.53 \%$ greater than the $-0.7 \%$ issue costs found by Mikkelson and Partch (1986) who only consider cash costs.

We can offer several explanations for the insignificant adjusted CARs for OTC and AMEX samples when both cash costs and underpricing are used. First, as we have illustrated, the greater issue costs for OTC and AMEX firms substantially reduce their traditional CARs. Second, offerings by OTC and AMEX firms are more frequently accompanied by positive wealth effects. This is especially suggested from the last column in Table 2, where we find a greater percentage of positive CARs for OTC and AMEX firms (43\% and $44 \%$, respectively) compared to NYSE firms $(32 \%)$. Unfortunately, we can find very little information from the financial press to indicate what reasons may be causing more positive CARs for OTC and AMEX observations. ${ }^{14}$

\section{Other Empirical Results}

We now report the results of other tests aimed at further increasing our understanding of the importance of issue costs. First, we separately test both the 241 primary offerings (consisting of 66 OTC firms, 73 AMEX firms, and 102 NYSE firms) and the 82 combination offerings (composed of 40 OTC firms, 34 AMEX firms, and 8 NYSE firms). We find that the negative cash flows caused by cash flotation costs and underpricing, as a percentage of outstanding common stock value, are $-1.54 \%$ for primary offerings and $-1.74 \%$ for combination offerings. Respective mean two-day CARs are $-2.39 \%$ and $-3.28 \%$. These results indicate that issue costs can account for $64 \%$ of the fall in stock value for primary offerings and $53 \%$ for combination offerings. For OTC, AMEX, and NYSE

${ }^{14}$ We leave it to future research to investigate, in detail, possible reasons for why OTC and AMEX firms have less negative adjusted CARS than NYSE firms. 
samples, the respective percentages are $94 \%, 73 \%$, and $36 \%$ for primary offerings, and $49 \%, 62 \%$, and $60 \%$ for combination offerings.

The lower $49 \%$ for our OTC combination offering sample is explained by the fact that the mean CAR for this sample is highly negative at $-4.30 \%$. This is about twice as negative as the $-2.30 \%$ found for our AMEX/ NYSE combination offering sample. Our OTC results resemble those of Hull and Fortin (1993/1994) who also find that about twice as much as the fall can be explained for OTC primary offerings as compared to OTC combination offerings. The market appears to suspect that combination offerings for OTC firms lead to greater insider sales for the secondary component of the offering. ${ }^{15}$

Next, we conduct tests when the sample is partitioned into three groups based on its value for the variable "Total Costs/Common Value." When performing a similar test, Hull and Fortin (1993/1994) find that one-third of the sample observations (with the greatest magnitudes for this variable) generate positive adjusted CARs that are statistically significantly different from zero. For our test, we discover a positive insignificant adjusted CAR. Since Hull and Fortin (1993/1994) include more than just cash flotation costs and underpricing when adjusting CARs, we repeat the test assuming additional costs besides cash cost and underpricing. Specifically, we assume that costs associated with warrants, the retirement of debt, and employees' time are roughly equal to underpricing. ${ }^{16}$ Adjusting CARs under this assumption, we find that the one-third of the observations with the greatest issue costs have an adjusted CAR of $+1.50 \%$, which is significant at the 0.01 level $(\mathrm{t}=2.75)$. The significance is not explained by outliers, as $61 \%$ of the observations are positive. A binomial two-tailed $\mathrm{z}$ statistic is significant at the 0.05 level $(\mathrm{z}=2.31)$.

Finally, we analyze those observations excluded from our tests by our last selection criterion, e.g., we examine those observations where the expected proceeds are less than $5 \%$ of the pre-announcement market value of common stock. Of these observations, there are 88 that have values greater than $0.5 \%$ (72 are NYSE firms). Cash flotation costs and underpricing as a percentage of outstanding common stock value average $-0.18 \%$ for these 88 observations. This percentage accounts for only $11 \%$ of the $-1.65 \%$ fall in

${ }^{15}$ Our OTC sample is smaller than Hull and Fortin (1993/1994) largely due to our last two selection criteria described in Section II, A.

${ }^{16}$ The cost of warrants, like underpricing, are relatively greater for OTC firms. It is generally believed that a warrant's exercise price is tied to the offering price, reinforcing the underwriter's incentive to underprice when warrants are used. Even though the use of warrants is more prevalent for firms with greater cash flotation costs and underpricing costs, $\mathrm{Ng}$ and Smith (1996) show that the use of warrants may still lower these costs below what might otherwise occur. stock value that occurs for these 88 observations. It is interesting to note that the $-1.47 \%$ difference when subtracting $-0.18 \%$ from $-1.65 \%$ is similar to the $-1.43 \%$ difference found for our NYSE sample. While one sample can account for only $11 \%$ of the fall in stock value, the other sample (i.e., the NYSE sample of 110 observations) can account for $37 \%$. Consistent with the issuance expenses model of Hull and Fortin (1993/ 1994), the extent to which issue costs can influence stock returns clearly can depend on the planned proceeds as a percentage of outstanding common stock value.

\section{E. Other Negative Wealth Effects}

We have offered evidence that the impact of issue costs is economically meaningful in its sheer magnitude. In addition, we provide empirical evidence concerning the importance of issue costs as evidenced by the insignificant CARs for the OTC and AMEX tests when the CARs are adjusted for cash flotation costs and underpricing. Our economically meaningful and statistically significant results suggest that the support for negative signaling/agency/tax effects (e.g., Fama, 1985; Myers and Majluf, 1984; Leland and Pyle, 1977; Ross, 1977; Jensen and Meckling, 1976; and Modigliani and Miller, 1963) given by prior research (e.g, Dierkens, 1991; Cornett and Travlos, 1989; Hull, 1994; Hull and Moellenberndt, 1994; Masulis and Korwar, 1986; and Masulis, 1983) may not individually or collectively be as important as generally believed.

However, we would like to emphasize that the significant relation between signaling/agency/tax effects and two-day CARs documented by prior research can still remain even if we adjust CARs for issue costs. For example, we repeat regression tests similar to those conducted by Hull and Moellenberndt (1994) but use adjusted CARs as the dependent variable. For brevity, we omit the details-but we can say that, like Hull and Moellenberndt, we find statistically significant support (albeit somewhat weakened) for signaling effects premised on changes in fractional holdings of insiders and actions by bankers. $^{17}$

\section{Conclusions}

In this study, we examine 323 common stock offerings

${ }^{17}$ Even if the negative announcement period effect can be attributed to the negative impact resulting from issue costs, it is still possible that managers are conveying negative information (albeit unsuccessfully) through equity offerings. For example, if the subsequent earnings (following equity offerings) are poorer than expected, then in retrospect one could infer that managers are signaling negative information. This possibility is supported by the longer run studies (e.g., Loughran and Ritter, 1995; and Patel, Emery, and Lee, 1994) that find equity issues are associated with negative information about future earnings. These findings can certainly suggest that managers expect unpleasant future prospects 
in an attempt to explain the apparently conflicting results obtained by prior research concerning the impact of issue costs on stock value. We also seek to investigate the situations in which issue costs can have a significant impact on stock value. To help achieve our aims, we separately examine OTC, AMEX, and NYSE listed samples for which we screen out observations that are not predicted to have large issue costs. Additionally, we test samples formed according to expected insider sales (namely, primary versus combination offerings) and according to the percentage change in equity.

Our findings suggest that equity offering studies should not ignore issue costs when trying to account for announcement period stock returns. For example, we find that mean cash flotation costs alone account for nearly two-fifths of the mean traditional two-day CAR. This is almost twice the impact found by prior research. The difference is explained by this study's stock offerings that have slightly more negative cash costs and substantially less negative two-day CARs. We also find that cash costs account for a greater percentage of the fall in stock value for OTC and AMEX firms as compared to NYSE firms.

We next examine the impact of issue costs when both cash costs and underpricing are considered. For these tests, we find that cash costs and underpricing

\section{References}

Asquith, P. and D. Mullins, Jr., 1986, "Equity Issues and Offering Dilution," Journal of Financial Economics (JanuaryFebruary), 61-89.

Brown, S. and J. Warner, 1985, "Using Daily Stock Returns: The Case of Event Studies," Journal of Financial Economics (March), 3-31.

Choe, H., R. Masulis, and V. Nanda, 1993, "Common Stock Offerings Across the Business Cycle," Journal of Empirical Finance (February), 3-31.

Copeland, T. and W. Lee, 1991, "Exchange Offers and Stock Swaps-New Evidence," Financial Management (Autumn), 34-48.

Cornett, M. and N. Travlos, 1989, "Information Effects Associated with Debt-for-Equity and Equity-for-Debt Exchange Offers," Journal of Finance (June), 451-468.

Dierkens, N., 1991, "Information Asymmetry and Equity Issues," Journal of Quantitative Analysis (June), 181-199.

Fama, E., 1985, "What's Different about Banks?" Journal of Monetary Economics (January), 29-39.

Finnerty, J., 1985, "Stock-for-Debt Swaps and Shareholder Returns," Financial Management (Autumn), 5-17. can account for over three-fifths of the mean traditional two-day CAR. Once again, issue costs account for greater proportions of the fall in stock value for OTC and AMEX firms. We also show that the inclusion of combination offerings dilutes the relative impact of issue costs on stock value (as these offerings have greater negative CARs). The test conducted on a group composed of the one-third of the sample firms undergoing the largest changes in outstanding common stock gives a positive CAR when adjusted for both cash flotation costs and underpricing.

We conclude that studies consisting of OTC and AMEX firms or of firms undergoing larger changes in equity are more likely (than NYSE firms or firms undergoing smaller changes in equity) to find that issue costs are a significant factor causing negative stock returns. Our findings offer support for issue costs models that predict that stock offerings cause a fall in stock value. Signaling, agency, and tax effects are still arguably present for many individual observations. However, event study research of equity offering announcements should not assume that these effects are always greater in magnitude, collectively, than an issue costs effect. In closing, our findings should help future research by explaining the effect that issue costs have on shareholder wealth.

Hand, J., 1989, "Did Firms Undertake Debt-Equity Swaps for an Accounting Paper Profit or True Financial Gain?" Accounting Review (October), 587-623.

Hull, R., 1994, "Stock Price Behavior of Pure Capital Structure Issuance and Cancellation Announcements," Journal of Financial Research (Fall), 439-448.

Hull, R. and R. Fortin, 1993/1994, "Issuance Expenses and Common Stock Offerings for Over-the-Counter Firms," Journal of Small Business Finance (No. 1), 1-17.

Hull, R. and R. Moellenberndt, 1994, "Bank Debt Reduction Announcements and Negative Signaling," Financial Management (Summer), 21-30.

Hull, R. and G. Pinches, 1994/1995, "Firm Size and the Information Content of Over-the-Counter Common Stock Offerings," Journal of Small Business Finance (No. 1), 31-56.

Ibbotson, R., 1975, "Price Performance of Common Stock New Issues," Journal of Financial Economics (October), 235-272.

Jensen, M. and W. Meckling, 1976, "Theory of the Firm: Managerial Behavior, Agency Costs and Ownership Structure," Journal of Financial Economics (October), 305-360. 
Jensen, M., 1986, "Agency Costs of Free Cash Flow, Corporate Finance, and Takeovers," American Economic Review (May), 323-329.

Leland, H. and D. Pyle, 1977, "Informational Asymmetries, Financial Structure, and Financial Intermediation," Journal of Finance (May), 371-388.

Light, J. and W. White, 1979, The Financial System, Homewood, Illinois, Irwin.

Loughran, T. and J. Ritter, 1995, "The Operating Performance of Firms Conducting Seasoned Equity Offerings," University of Illinois at Urbana Champaign Working Paper.

Masulis, R., 1983, “The Impact of Capital Structure Change on Firm Value: Some Estimates," Journal of Finance (March), 107-126.

Masulis, R. and A. Korwar, 1986, "Seasoned Equity Offerings: An Empirical Investigation," Journal of Financial Economics (January/February), 91-118.

McDaniel, W., J. Madura, and A. Akhigbe, 1994, "The Valuation Effects of Frequent Common Stock Issuances," The Journal of Financial Research (Fall), 417-426.

Mikkelson, W. and M. Partch, 1986, "Valuation Effects of Security Offerings and the Issuance Process," Journal of Financial Economics (January/February), 31-60.

Miller, M. and K. Rock, 1985, "Dividend Policy Under Asymmetric Information," Journal of Finance (December), 1031-1050.
Modigliani, F. and M. Miller, 1963, "Corporate Income Taxes and the Cost of Capital: A Correction," American Economic Review (June), 433-443.

Myers, S. and N. Majluf, 1984, "Corporate Financing and Investment Decisions When Firms Have Information that Investors Do Not Have," Journal of Financial Economics (June), 187-221.

Ng, C. and R. Smith, 1996, "Determinants of Contract Choice: The Use of Warrants to Compensate Underwriters of Seasoned Equity Issues," Journal of Finance (March), 363-380.

Patel, A., D. Emery, and Y.W. Lee, 1993, "Firm Performance and Security Type in Seasoned Offerings: An Empirical Examination of Alternative Signaling Models," Journal of Financial Research (Fall), 181-192.

Peavy, J. and J. Scott, 1985, "The Effect of Stock-for-Debt Swaps on Security Returns," The Financial Review (November), 303-327.

Rogers, R. and J. Owers, 1985, "Equity for Debt Exchanges and Shareholder Wealth," Financial Management (Autumn), 18-26.

Ross, S., 1977, "The Determination of Financial Structure: The Incentive-Signaling Approach," Bell Journal of Economics (Spring), 23-40.

Scholes, M. and J. Williams, 1977, "Estimating Betas from Nonsynchronous Data," Journal of Financial Economics (December), 309-328.

Smith, C., 1977, “Alternative Methods for Raising Capital," Journal of Financial Economics (December), 273-307. 